\title{
The Trace of the Untranslatable: Emmanuel Levinas and the Ethics of Translation
}

\author{
Dorota Glowacka
}

\begin{abstract}
Heart:
Make yourself known even here, Here in the midst of the market.

Cry out the shibboleth

Into your homeland strangeness.

(Paul Celan, "Shibboleth")
\end{abstract}

In a short piece entitled "Conversation in the Mountains," Paul Celan describes two Jewish wonderers, the inhabitants of the land, who gaze from the top of a hill upon the fertile, green valley underneath and muse about the language that belongs to that place:

that's the kind of speech that counts here, the green with the white in it, a language not for you and not for me-because I am asking, who is it meant for then, the earth, it's not meant for you, I am saying, and not for me-well then, a language with no I and no Thou, pure He, pure It, d'you see, pure They and nothing but that. (398)

The allegory recounts the Jewish stranger's condition of perennial exile from his linguistic community, whereby the language of the country in which he lives, indeed, his mother tongue, has never belonged to him. The excluded other in the green lands of sameness, the stranger always speaks as if in a foreign tongue.

In another poetic commentary on language - the poem entitled "Shibboleth"-Celan alludes to the biblical episode in which the Ephraimites, trying to cross the river Jordan, are killed by the Israelites because they cannot pronounce the sound "Sh" (ש) in the secret password "Shibboleth," saying "s" (ש) instead (Judg. 12.6). If one’s ability to pronounce certain words 
presupposes belonging to a linguistic community, the shibboleth, in Jacques Derrida's words (from his commentary on Celan's poem), grants one "the right of asylum or the legitimate habitation of a language ... indeed, the right to live" (Sovereignties 26). ${ }^{1}$ Yet the shibboleth of the mother tongue is a double-edged sword: it can become a sentence of exclusion, even a death sentence, as it befell the Ephraimites, but also (later in history), the Eastern European community of the speakers of Yiddish.

The events of the Holocaust excluded Celan and many others like him—strangers who speak in a "circumcised word"-from the human community (Celan 171). As a result, the genre of Holocaust testimony, of which Celan's poetry is an example - the writing of the disaster that proliferated in the decades after the war-is also testimony to the vicissitudes of translation. In what follows, I will argue that, at least within the purview of Holocaust témoignage, though by no means circumscribed by it, translation is imbued with an ethical demand and must be reevaluated in the context of ethics. Or, insofar as translation bears witness to the inscription of alterity in the language of a community, the visitation of the stranger who has arrived from "planet Auschwitz," the sounds of his or her voice, wounded and often marked with an accent, situates translation as always already an ethics.

I will reflect on translation's ethical exigency after the Shoah in relation to Emmanuel Levinas' hyperbolic articulation of ethics as responsibility to and for the other. At the same time, I will pose a question about the place of translation in Levinas' own work, despite the philosopher's ostensive silence on the subject. "Translation" will be understood in a broad sense as both rendering a text into another language, and as exchanges and interactions between languages that take place within a given a text. Holocaust testimony is a case par excellence of the dilemmas of translation because of its paradigmatic condition of linguistic dislocation, as it 
often manifests itself in the "foreignness" of the testifying voice. In the most literal sense, in the hundreds of thousands of oral testimonies now deposited in video archives (for instance, the USC Shoah Foundation Institute, the Fortunoff Video Archive for Holocaust Testimonies at Yale, the United States Holocaust Memorial Museum, and Yad Vashem's collections) or documented in films such as Claude Lanzmann's Shoah, Holocaust survivors speak with heavy accents, betraying their exile from the linguistic communities of their birth. Although the audible mark of foreignness disappears in written accounts, it is significant that a majority of written Holocaust testimonies were produced in a language that was not the author's mother tongue, including those in the philosophical genre, such as Emil Fackenheim's To Mend the World. At the same time, Holocaust survivors who did write in their first language, such as Celan, Jean Améry, Primo Levi, or Imre Kertész, would confess a sense of strangeness and alienation from their immediate linguistic surroundings. Like Celan's wonderers, they wrote in the mother tongues in which they had always been foreigners, the condition that became infinitely exacerbated after Auschwitz, which had rendered that linguistic exile permanent and irreparable (Kertész 177).

Because of its unassimilable nature, the traumatic experience of the Shoah has been referred to as "untranslatable" also in a psychoanalytic sense. In the words of trauma theorist Cathy Caruth, a traumatic event is "the breach in the mind's experience of time, self, and the world, and as such cannot be known at the time of its occurrence" (2-4). It can never be experienced directly and thus marks an interval in the temporality of the subject. Since it remains unabsorbed into the subject's psychic apparatus, it returns to haunt him or her later on. The symptoms of trauma resurface as nightmares, but they can also manifest in the subject's unknowing acts, which Freud diagnosed as repetition compulsion. These unintended, compulsive 
gestures also include speech acts; language thus carries traces of trauma, often against the subject's intention or will. In many instances of Holocaust testimony, the disjunction between language and the experience it is seeking to describe is magnified because bearing witness to what happened takes place in a foreign tongue. The psychoanalytic cure involves working through the traumatic event and eventually domesticating it in language, even though this language remains radically foreign to what it is trying to describe. In that case, what happens in the passage between the linguistic environment in which trauma was (not) experienced and the survivor's second language, in which testimony is given?

Undoubtedly, the relation between trauma and language is relevant to Levinas' oeuvre, at least insofar as we interpret his work as underwritten by the imperative to bear witness to the Shoah, to "the hatred of the other man," in the medium of philosophy, although its testimonial scope must not be reduced to this particular historical trauma (epigraph to Otherwise than Being). In Philippe Nemo's words, the Holocaust was “a hidden referent" around which Levinas' work was organized (quoted in Malka xi), while Howard Caygill proposes that both Totality and Infinity (1961) and Otherwise than Being (1974) are veiled "works of mourning for the victims of National Socialism" (Caygill 5), and Michaël de Saint Charon claims that Levinas' lifelong work on developing an ethics of infinite responsibility was meant to be a "justification of living after Auschwitz" (de Saint Cheron xi). ${ }^{2}$ Levinas' life and work were marked by the tragic events of the Shoah, although in his major works he remained silent on the subject. Direct-if undeveloped - references appear in shorter texts, such as "The Struthof Case," "The Name of the Dog, or Natural Rights," "Nameless," or "Useless Suffering," and perhaps most notably in a brief text at the end of Difficult Freedom, entitled "Signature," where Levinas concludes a summary of his "intellectual biography" with a statement that "It [his work] is dominated by the 
presentiment and the memory of the Nazi horror" (291). In his essay, "Loving the Torah more than God," an unusual text for the philosopher since it was a review of a work of fiction (the Holocaust-inspired novella "Yosl Rakover Speaks to God,” by Israeli writer Zvi Kolitz), Levinas explains that his reluctance to write about the Shoah stems from a refusal "to offer up the ultimate passion as a spectacle and to use these inhuman screams to create a halo for myself as either author or director. The cries are inextinguishable; they echo and echo across eternity. What we must do is listen to the thought they contain" ("Loving the Torah" 81 , emphasis mine). Thus, although Levinas questions appropriative thematization of horror and suffering, he also emphasizes that the impact of the events is enduring and insists that his task as a thinker "after Auschwitz" is to listen to the cries of the victims.

We must note, however, that the philosopher's life and work were also affected by linguistic and geographical migrations: he was a Lithuanian Jew, raised in a Russian and Yiddish speaking household. When he moved to France in 1923 to pursue his studies at Strasbourg, he adopted French as the language in which he subsequently wrote all of his work. In the Foreword to Malka's biography of Levinas, Philippe Nemo writes that after Levinas came to live in France, he made "an unwavering rational and spiritual decision" to be loyal to that country, and this observation can surely be extended to Levinas' "loyalty" to the French language (Malka vii). ${ }^{3}$ Unlike Hannah Arendt, who often spoke with fondness about her native German and her conscious effort to preserve it, ${ }^{4}$ or Celan, whose poetry plumbs the tortured paradoxes of his relation to his Muttersprache (which also became for him the language of barbarism and "the thousand darknesses of deathbringing speech"), Levinas never commented on the role of his native tongue in his work (Celan 395). Scarce references to Yiddish appear in some interviews; he told Myriam Anissimov, for instance, that: "My parents spoke Yiddish, and knew a lot of 
Hebrew, but they always spoke Russian with the children" (Robbins 84). In an interview with Raoul Mortley, he stated that "being Jewish we spoke Yiddish" and hastened to add that the significance of his knowledge of Yiddish, the language commonly attributed to unenlightened Ostjuden, had given him a good grounding in German, which would soon enable him to read Heidegger (Mortley 12). In hindsight, considering Levinas' ambivalence toward Heidegger after the war, his allusion to accessing Heidegger's writings indirectly via Yiddish is tragically ironic, especially if this were to be the only extant trace of that forgotten language in his work. The love of Russian, on the other hand, comes across in Levinas' frequent references to the classics of Russian literature, which he puts on a par with "the Bible and the philosophers," in terms of a formative influence on his thinking, even though he never mentions that language as such or plays with its etymologies, as he does in French (Levinas, Ethics and Infinity 22). Since his native Russian remained an active language for Levinas, it could not have escaped his attention, for instance, that the word for "responsibility" in Russian, “Ответственность," is closely related to "Ответ" ("response") and отвечать ("to respond"). Yet the philosopher highlights this etymological derivation in French, and it crucially informs his conception of Saying (le Dire) as the discursive manifestation of my responsibility for the other. Unlike his silence in Yiddish, Levinas' fluency in Hebrew was exemplary, and, as attested in Levinas' Talmudic texts, which he insisted on keeping separate from his properly philosophical texts, so was his love of Hebrew etymologies. Indeed, since his childhood, Levinas studied Hebrew, the language of Mitnaggedim (Enlightenment) Jews and the Gaon of Vilna. Let us also note, in parentheses, that although Lithuanian was not spoken in the Levinas household, his last name, unique among the French noms propres, identified him unmistakably as a Lithuanian Jew: a majority of Lithuanian proper 
names of people and places end in "-as" (as in "Kaunas," the city in which Levinas was born). In this case, the ending "-as" is added to a very common European Jewish name "Levi."

During the war Levinas enlisted in the French army as an interpreter (of Russian and German), and in 1940 he was captured and sent to a POW labour camp. With the exception of the short, incidental pieces mentioned above, and some comments in the interviews, we know very little of the almost five years spent in German captivity. Even those references to his own experience of "physical torture, cold and hunger or discipline, things stronger than death" have been eclipsed in Levinas scholarship by the fact that it is in the camp that he started working on his first important work, Existence and Existents (1947), which is an engagement and polemic with the phenomenology of Husserl and Heidegger ("The Struthof Case" 149).

According to his biographer Solomon Malka, Levinas spoke French with a heavy Slavic accent, for which he was derided by his pupils at ENIO (École normale israélite oriental), ${ }^{5}$ while his written work bore a mark of anguished struggle with the French syntax and vocabulary-a silent testimony to the loss of his mother tongue. In contrast to Levinas, Belgian philosopher Jean Améry (formerly Hanns Chaim Mayer) openly mourned that loss. An Austrian Jew from an assimilated German speaking family, Améry bemoaned that the linguistic dispossession had dismantled his sense of self, even though he continued to write his major works in German (including Jenseits von Schuld und Sühne, translated into English as At the Mind's Limit). Although French was his language of everyday use, in this second language "he will always stumble around as if I were drunk" (Améry 48). French would never become "a real friend": " $L a$ table will never be the table (der Tisch): at best one can eat one's fill at it" (52). Presumably, Améry's reflection on his anguished relation to French, adopted by necessity after the war, aptly describes Levinas' sense of discomfort in his second language. 
Considering Levinas' linguistic peregrinations and his multilingualism, it is intriguing that, throughout his profoundly innovative reflection on the ethical essence of language, he never comments on the question of translation. Neither does he reflect on the condition of being exiled from language, let alone on his own estrangement from the French language in which he wrote. In Otherwise Than Being, Levinas argues that language is primarily constituted by the self's aptitude to respond to the call of the other, and he distinguishes between language as the preoriginal, ethical Saying that signifies as a one for the other, and language as the Said that merely communicates meaning and betrays alterity by bringing it into disclosure. He writes, "The responsibility for another is precisely a saying prior to anything said. The surprising saying, which is a responsibility for another is against 'the winds and tides' of being, is an interruption of essence" (43). While language "as a thematization and an identification in which being is as it were set" is impersonal and belongs to the order of truth and being, its ethical essence is the proximity of the interlocutor, a contact between me and the absolute singularity of the other, “tenderness and responsibility" (Levinas, "Language and Proximity” 116).

In the seminal chapter of Otherwise Than Being, entitled "Substitution," Levinas relates his reflection on Saying and the Said to a conception of the ethical subject whose primordial, pre-ontological condition is displacement from "home," a violent eviction from chez soi, precipitated by its irremissible responsibility for the other. Levinas' insistence on the egotistic correlation between language and dwelling in one's home without doubt echoes and critiques Heidegger's famous formulation in "Letter on Humanism" (1947) that: "Language is a house of Being. In its home man dwells. Those who think and those who create with words are the guardians of this home. Their guardianship maintains the manifestation of Being insofar as they bring the manifestation to language and maintain it in language through their speech" (Basic 
Writings 193). Let us recall that in his later writings on language Heidegger qualifies his earlier statement by adding that "Language is the house of Being because language, as Saying, is the mode of Appropriation" (Way to Language 135). It seems that even though Heidegger revised his thinking to open language to Being's infinite gifting, Levinas abides by his interpretation of Heidegger's Saying as a manifestation of conatus essendi-man's egotistical relation to his existence. Levinas refused to listen to "later" Heidegger despite his enduring admiration for Being and Time (which, in his view, brought Western metaphysical rationality to an end), possibly contingent on his inability to forgive Heidegger for his silence concerning the Shoah, the silence "cut off from any sensitivity, in which can be perceived a kind of consent to horror" (Levinas, “As if Consenting to Horror" 487). The unforgivable nature of Heidegger's silence also would have prevented Levinas from hearing the German philosopher's important musings on the question of translation, that is, on the possibility of "a dialogue from house to house" (Way to Language 5). As Heidegger conjectures in "Dialogue on Language," this possibility stems from a common region of nameless "beckoning stillness," from whence comes a message to man, "a call calling from afar," to which Heidegger refers as Saying (die Sage) (45).

In Levinas' silence on translation one moment stands out: the double epigraph to Otherwise than Being. The version in French is dedicated "To the memory of those who were closest among the six million assassinated by the National Socialists, and of the millions on millions of all confessions and all nations, victims of the same hatred of the other man, the same anti-Semitism." The dedication in Hebrew, placed beneath, commemorates Levinas' loved ones, who perished in mass executions in Kaunas:

To the memory of my father and master, Rabbi Yehiel son of Abraham the Levite [haLevi], my mother and guide, Dvorah daughter of Rabbi Moshe, my brothers Dov son of Rabbi Yehiel the Levite [ha-Levi] and Aminidav son of Yehiel the Levite [ha-Levi], my 
father-in-law Rabbi Shmuel son of Rabbi Gershom the Levite [ha-Levi] and my motherin-law Malka daughter of Rabbi Chaim. May their souls be preserved in the bond of life. (Malka 81, translation modified)

Yet even in this rare autobiographical moment, which can be seen as a symbolic textual matzevah for his murdered relatives, Levinas chooses Hebrew rather than his mother tongue Russian, or Yiddish, the languages spoken by those whose names he commemorates. Here, the absoluteness of Levinas' silence about Russian and Yiddish, or, should we say, his silence in Russian and Yiddish, betokens the unspeakable loss of those who spoke those languages and who were "closest" to the philosopher.

Levinas' silence, which envelops the place in which the closest to him were murdered, partakes therefore of the landscape of linguistic devastation after the war. The annihilation of the entire Eastern European Yiddishkeit and the displacement and dispersal of its remnants nearly spelled the death of the Yiddish language, including the impossibility of giving testimony to that disappearance in Yiddish. A poignant case of the loss of the Yiddish speaking community was Elie Wiesel's reworking of his memoir Un di Velthot geshvign (And the World Was Silent) into what is now known as La Nuit, a translatory feat that enabled him to emerge from traumatized silence and craft his entire life as a paradigmatic witness to the Shoah. ${ }^{6}$ As mentioned before, a majority of survivors from Eastern Europe eventually wrote their memoirs or gave oral testimony in their second language, and the choice of the language in which they wrote had an impact on their strategies of self-identification, including the content of their memory. Some scholars who have interviewed survivors claim that the truth of the traumatic experience can only be expressed in the language in which it happened. ${ }^{7}$ Others report that, exactly because the "truth" of the experience is so strongly associated with one's native tongue, a neutral, distant language can act as a protective shield, thus enabling the survivor to break the silence. As 
Holocaust historian and writer Yaffa Eliach notes, "Sometimes the language stands between the writer and the horrors of the Holocaust, in that it permits him to grapple with the Holocaust in a language other than that in which he experienced it. Consciously, or perhaps unconsciously, the new language has the power to attenuate slightly the fiery pain" (quoted in Rosen 11). Thus, by refracting memory through translation, authors of Holocaust testimonies abdicate the "truth" of traumatic events and allow their new linguistic medium to expropriate it. At the same time, the second language has an amnesiac, palliative effect, which allows them to master the fragmented, uncontainable experience.

Kertész, Holocaust survivor and Nobel Prize laureate, once said that he writes about the Holocaust because it "does not have a language"; that is, no national language has been able to coin the words that would contain its experience (Kertész 204). Because of national languages' fundamental incapacity for expression vis à vis the Holocaust, the survivor dwells as a stranger in the "house of language," being only able to express himself in an accidental, "borrowed tongue, which in its nature rejects [him] or only tolerates [his] presence on the peripheries of its consciousness" (204, translation mine). The "unclaimed experience" (Caruth's term) of the Shoah is extraterritorial with respect to national languages, although in the accented speech of the survivors its symptoms return as the lost language's unassimilable remainder. We have stated that Levinas' entire philosophical project is a protestation against the violence directed at another man, unleashed by the Shoah. In his post-Auschwitz reflection The Drowned and the Saved Primo Levi writes, "It is an obvious assertion that where violence is inflicted on men, it is also inflicted on language," that "necessary and sufficient instrument for man to be man" (Levi 97). The precarious condition of post-Holocaust language stems directly from the Nazi assault on the essence of man as zōon logon echōn. Yet this violence was manifested in an attempt to 
exterminate particular national languages, through a decree that those who spoke them should die. Thus the conundrum of post-Holocaust speech lies in the imperative, now incumbent on survivors, to translate into a national tongue the experience of the annihilation of his or her intrinsically human ability to address another and to be addressed. In that case, would the way out of this aporia lie in a search for a translinguistic horizon that would transcend the manifestation of testimony in a national tongue? It can be argued that this linguistic perplexity traverses Levinas' work, despite his silence on the subject of translation, and it necessitates the question about the impact of the disavowed linguistic estrangement on the philosopher's work, beyond what Malka describes as his clumsy French syntax. It is conceivable, moreover, that the translatory struggle in his texts and the inevitable perplexities of traduttore traditore animate a testimonial impetus in Levinas' oeuvre.

Since Levinas was silent on the question of translation, let us turn to Walter Benjamin, a theorist of translation and an acclaimed translator, whose life was also tragically marked, first by anti-Semitic legislation in Nazi Germany and then by the events of the Shoah. In his seminal essay, "The Task of the Translator" (a Preface to his translation of Baudelaire's Tableaux parisiens, 1923), Benjamin writes that the task of translation is to redeem language's postBabelian predicament and to bring the dispersed tongues closer to what he calls "pure language." Echoing the cabbalistic legend of the vessel in which angels carried divine light until it became too heavy, fell, and shattered into millions of pieces, the prelapsarian pure language is the "inaccessible realm of reconciliation and fulfillment between languages," in which the fragments scattered and abandoned across different languages are to be gathered and rejoined (Benjamin, Illuminations 75). This means that languages are a priori interrelated by a "weak" messianic promise, and translation can bring out their higher kinship. Every language then possesses an 
inherent quality of translatability, regardless of whether a person will ever be found capable of translating it. In its promise of communicability between languages, an actual work of translation thus beckons toward the horizon of linguistic possibility — an unreachable limit to which every text is destined. In that sense, translation's "fidelity" to the original does not mean that it reproduces the original, but that it produces an effect of harmony and reflects "the great longing for linguistic complementation" (79). In reaching out toward pure language from within a particular language, translation always addresses itself to a wholly other tongue. Yet as Paul de Man (like Benjamin, a native speaker of German) pointed out, the English translation of the title of Benjamin's essay obscures the fact that the German word for task, die Aufgabe, also connotes giving up or failing (de Man 80). Translation necessarily fails to attain the goal of perfect communication, while the ideal horizon remains at a distance. This defeat, this betrayal intrinsic to every act of translation, however, stems from the lack in the very language of the original, from its failure to express what it must have disarticulated and sent into exile in order to constitute itself within native borders. Translation then reveals "the suffering of the original language": the fact that exactly in the place where we feel most at home and familiar-in our mother tongue - "this alienation is the strongest" (de Man 84). And this is why, ever since Babel, languages are destined for translation; why, as Jacques Derrida writes in his essay on Benjamin, "Les Tours de Babel," the translator's task is a mission— "the commitment, the duty" — to reveal a language's originary indebtedness to what it has excluded (177). We do not know to whom the translator is obligated, but it is from the place of this inarticulable, untranslatable alterity inherent in every national language that a work calls for translation. This is why, as Benjamin writes, "the task of the translator is to release in his own language that pure language which is under the spell of another to liberate the language imprisoned in a work in his re-creation of the work" 
(Illuminations 80, emphasis mine). Translation renders the familiar sounds of the native tongue foreign, uprooted from their native soil, unheimlich, exposing the traces of what the language has expropriated. It thus allows the mother tongue to be "powerfully affected" by the foreign language to which it remains indebted, and it foregrounds the invisible marks of that inscription (Illuminations 81).

Translation bears witness to the original text, thus enabling its posthumous survival (übersetzen is always a hope for überleben, for a "stage of continued life") while at the same time it reveals the essence of my language as bound to another tongue (71). Here Benjamin's articulation of the translator's task in terms of witnessing and indebtedness resonates with Levinas' idiom of the responsibility of the ethical subject who always bears witness to the other in her speech: "The subject, in which the other is the same, insomuch as the same is for the other, bears witness to it" (Otherwise 146). In this primordial capacity, the subject is the addressee of a command or a plea coming from the other, who cannot be seized in recollection and thus reduced to the truth of disclosure. Prior to intentionality and will, the infinite other is glorified in my speech because " $[\mathrm{He}]$ command $[\mathrm{s}]$ me through my mouth ... and orders me by my own voice" (Ethics and Infinity 110). Thus the ethical subject, affected by the other to the core of its being, testifies to the source of its own obligation, the source that is radically external, cannot be derived from consciousness, and remains unknown. The self, writes Levinas, is like a sound "that would resound in its own echo, the node of a wave which is not once again consciousness" (Otherwise 103). The echo carries the trace of the other in my voice even against my intention, attesting to the indisputable fact of her existence "through what it is capable of doing in the witness" (Ethics and Infinity 145). 
Perhaps it is no coincidence therefore that the affinity of the idiom of witnessing in Levinas and Benjamin is reflected in both thinkers' recourse to the figure of the echo. Benjamin writes, "The task of the translator consists in finding that intended effect (Intention) upon the language into which he is translating which produces in it the echo of the original" (Illuminations 76). Perched on the periphery of language, translation calls into the "language forest ... it calls into it without entering, aiming at that single spot where the echo is able to give, in its own language, the reverberation of the work in the alien one" (76, emphasis mine). Although it does not enter "the green valley" of my linguistic community (Celan 396), translation striates my tongue with the traces of the foreign, whereby my own language, the hearth of my identity, suddenly becomes "alien" in its own home, unheimlich. The trope of the echo conveys that translation is a response to the summons from another language, the language of another. It reveals that my ability to speak, that is, my membership in a linguistic community, is constituted in the movement of returning home from an encounter with another tongue. On the other hand, the speech of an exile from the community calls for translation because it is testimony to a trace of strangeness sojourning in "the midst of the market."

For Levinas, self-identity arises from the impossibility of escaping ethical assignation; that is, responsibility is the primary and fundamental structure of subjectivity. As he elaborates in Otherwise Than Being, the subject is individuated in "recurrence," a repeated movement of going outside of oneself and withdrawing into oneself, which is precipitated by encounters with a being that dwells outside the horizon of my world and, arriving from the "immemorial past," never coincides with me temporally ("The Trace of the Other" 353). In recurrence, the same substitutes for another "on the hither side of its own identity," putting itself in someone else's place to the point of being her hostage and expiating for her faults (Otherwise 139). Unlike in 
Hegelian recognition, where the encounter with the other culminates in the absorption of the non-identical, in recurrence, the ethical subject is turned toward the other who cannot be assimilated to the structures of the self. As a result, the endless movement of return from the outside disallows the subject to coincide with itself, disrupting self-presence and self-possession. This repetitive mis-encounter with oneself is thus "an exigency coming from the other over and above the active dimension of my powers, so as to become a departure without limits in which the self spends itself without counting" (Levinas, God, Death, and Time 179). The self is, first and foremost, for the other because prior to having ventured outside of itself, it has already returned from a (non)place of absolute exteriority, which it can never inhabit. Originating in recurrence as the infinite movement of primordial ethical obligation, the self is displaced and uncomfortable, "twisted over itself in its skin, too tight in its skin, in itself already outside of itself" (Otherwise 104). It loses the fulcrum of self-identification, unable to find itself chez soi: "before the exigency of the other, the I is expelled from this rest, and is not the consciousness of this exile" ("The Trace" 353, emphasis mine). The ethical subject is evicted from its "place in the sun ... the beginning of all usurpations," and its Being-in-the world, its very right to be, is radically questioned (Pascal, frequently quoted by Levinas, Robbins 62).

Benjamin's thesis on "pure language" reveals that I come into being as a speaking subject, a member of a linguistic community, because I am indebted to what remains outside the frontiers of my language, on the periphery of its thicket of words. If a Levinasian ethical subject is born in the infinitely repeated journey toward the other, translation, by its nature, is already a repetition. It is a return to the same in a different tongue, whereby the original comes back as a gift of another language. The translatory exigency is therefore undeclinable and irreducible: in her border-crossings between languages the translator is always oriented toward the ethical 
horizon, although in her everyday practice she attends with solicitude to the plastic and contextually moulded surface of language, where meanings and themes are communicated. What Levinas calls the Said always appears in its concrete manifestation as a national language. In that sense, any act of translation is a double betrayal, effacing the very thing it seeks to preserve and failing to deliver what it has been consigned to bring forth. We can then postulate that Levinas conceives of Saying as a moment that escapes both thematization in the Said and the totalizing intention of a particular tongue. At the same time, since my voice carries the trace of radical alterity and bears witness to it, the Said is necessary: I must not remain silent "be it at the price of a betrayal" (Otherwise 6). Furthermore, in language as it is ethically conceived, silence itself belongs to speech and signifies by its effacement of the communicating word. We can then say that Levinas' Said is a manifestation of the Benjaminian paradox of traduttore traditore - of any particular tongue's necessary failure (which, as de Man brings out, is also a felicitous one). We can postulate therefore that Levinas' articulation of Saying, as it always overflows the imperfect vessel of thematic language and undoes its form ("the inevitable paralysis of manifestation"), quietly echoes Benjamin's conception of "pure language"-the horizon of communicability between languages, toward which the text is solicited by a call from another tongue ("The Trace" 352). For Benjamin, the allegory of the Tower of Babel symbolizes the inferiority of the words with which man names things with respect to God's infinite word that speaks things into existence (Reflections 318). While Benjamin's attention to the plurality of Babel allows us to anchor Levinas' Saying in a particular linguistic community of the Said, Levinas' insistence on Saying's ethical orientation, which issues from the irreducible singularity of the other, re-situates Benjamin's translator face to face with a language user. It is as a suffering, vulnerable existent that a speaker of language walks in the trace of God ("The Trace" 359). 
The above reflection on Levinas' linguistic peregrinations, in the literal sense of exile and the crossing of national frontiers as well as in his reflection on language, has led me to a twopronged conclusion. In a larger framework, an approach to the question of translation in which Levinas' thesis about the ethical essence of language is augmented with Benjamin's sensitivity to the plurality of languages might be the right step toward developing a theoretical framework in which to consider the dilemmas of translation in Holocaust testimony, which, with a few notable exceptions, have so far received little critical attention. ${ }^{8}$ The specific weakness of Holocaust testimony - the absence of a language in which it nevertheless must be conveyed - makes it vulnerable to appropriation. Within the scope of Levinas' ethics, which I have expanded so that it can encompass the problem of translation, this weakness is also its greatest strength in at least two respects. As is apparent in many a Holocaust memoir, and mentioned here in reference to Levi and Kertész, Holocaust testimony foregrounds the communicative imperative and is structured as an address to another, demanding a response. In its plea, "Are you listening?" "Please listen!" its function is primarily phatic and ethical (rather than cognitive), and the speaking subject emerges as the inscription of the trace of the other, who addresses it from the past that is inaccessible in memory.

In his eulogy for Levinas, included in Adieu for Emmanuel Levinas, Derrida reminisces that when talking on the phone Levinas would frequently repeat “'Allô, allô' between each sentence, sometimes even in mid-sentence" in a voice strained with worry that the communication might have been interrupted (9). This linguistic gesture is telling of Levinas' concern for the other's non-response, his solicitude for what he calls the expressive function of 
language — its "signifyingness of signification" that is primarily the turning of the ear toward the other, prior to the content and intention of the message. As he says in one of the interviews, "Should language [not] be thought ... perhaps above all—as the fact of encountering the other as other, that is to say, already as response to him? Is not the first word bonjour? ... I wish you peace, I wish you a good day, expression of one who worries for the other" (Robbins 47). In this concern, Levinas' conception of language resonates with the plea to listen that structures every Holocaust testimony, with its primary function as interpellation.

Translation is then central to Holocaust testimony because, oriented toward an inaccessible region of linguistic complementarity, it is primarily an articulation of the hope of communication, of the tikkun (mending) of language, against the Nazi destruction of language as an address to another. ${ }^{9}$ Its function is to initiate and sustain communication and to transmit a plea for a response. As we read in many survivor memoirs, in the Nazi camps the knowledge of German and one's translatory abilities were the prime mechanism of survival. Levi describes Auschwitz as "a perpetual Babel, in which everyone shouts orders and threats in languages never heard before, and woe betide whoever fails to grasp the meaning" (Survival in Auschwitz 38). It is striking that, in many passages in both Levi and Kertész, being able to speak German but also the other languages of the camp is associated with nourishment, specifically with bread and soup. Levi recalls, for instance, that he was absorbing foreign words and expressions "like a famished stomach rapidly assimilates even indigestible food," and he trades a daily portion of bread for a lesson of German, commenting that: "never was bread better spent." Survival depends on one's translating abilities and linguistic talents, which enable one to secure an extra slab of "breadBrot-Broid-chleb-pain-lechem-keynér" (Survival in Auschwitz 39). When giving an apparently arbitrary example of languages' intention to communicate, Benjamin (like Levi) tellingly 
chooses the word for "bread," the symbol of nourishment and preservation of life: "the word Brot means something different to a German that the word pain to a Frenchman (Illuminations 74). Translators bear witness to that difference, and they do so by lending an ear to the other, by exposing themselves to the alien sounds that they make reverberate in their native tongue. In another convergence of metaphors, Levinas repeatedly tropes responsibility as giving to another the bread taken away from my mouth. Here, "bread" is the cipher for the ethical imperative that the preservation of the life of another is more important than my own life.

Kertész asks, with respect to the question of language after the Shoah: "For whom is this language destined?" (181) According to Celan, a poem is "a message in a bottle, sent out in the - not always greatly hopeful—-belief that somewhere and sometime it could wash up on land, on heartland perhaps" (396). It is a gift destined to an unknown future, and its hope "has always been to speak ... in the cause of an Other- who knows, perhaps in the cause of a wholly Other" (408, emphasis in original). Like Celan's poetic speech, the translating word drifts toward the unknown for the sake of an encounter, opening the door to the other who arrives from the future, and it is already marked by the accents of those to whom it is addressed. That is why the task of the translator is to interrupt a national language's complacency by disseminating the echoes of foreign word-visas without which linguistic borders would remain impassable. In the process, native words are transformed from an inscription of belonging into the mark of strangeness. They are evicted from what is most properly "mine" and dispatched toward an experience of the multiplicity of languages. Because it brings out the mark of difference on the body of language, translation, as Derrida argues in his reading of Celan's Shibboleth, is a promise of undoing the totality of linguistic privilege, of dismantling the assertions of supremacy of one language over the other. Reconceiving translation in Levinasian terms, therefore, as primarily oriented by 
ethical Saying leads us to articulate "the task of the translator" after the Shoah as an injunction to national languages to be deeply self-reflective about what they have excluded. Since Holocaust testimonies always involve some form of translation or translatory mis-encounters, they reveal the intrinsic vulnerability and "homelessness" of language. In resisting one particular language's claim to superiority and linguistic hegemony (the German language's, for instance), they gesture toward a possibility of communities of speakers that would come into being along different and multiple axes of linguistic belonging.

On the other hand, rethinking the question of translation in relation to Levinas' own work, in which it has been strangely disavowed, leads us to conceive of translation as the cipher for what Levinas calls witnessing. This insight may allow for a more nuanced understanding of Levinas' conception of language as always already beholden to another in its ethical essence. Levinas construes Saying — an aptitude to listen with an ear always turned toward the other-as a translinguistic horizon, over and beyond its disclosure as a linguistic phenomenon. Saying, which signifies responsibility and marks my own speech with the trace of the other, can never be reduced to the Said, to that which, as Levinas does not say, always takes place in a particular national tongue.

Yet I remain intrigued with Malka's testimony that traces of linguistic otherness are impressed on the body of Levinas' work; his is a circumcised word, to recall Celan. Even if this moment of linguistic alterity remains unthematized throughout his oeuvre, otherwise entirely dedicated to alterity, Levinas' silence on the question of translation is revealing. It is possible to argue that Levinas' exile from his native Russian and Yiddish speaking linguistic community, his activity as an interpreter, which likely helped him survive the Holocaust, ${ }^{10}$ as well as his translatory struggles throughout a lifetime of writing, profoundly informed his thinking about 
language as primarily listening to the other, even though in his work he refrained from reflecting on this debt. Or perhaps, following the threads in Levinas' own oeuvre, we can think of this silence, so deeply intertwined with his silence about the Shoah, as itself a non-phenomenal trace of this debt.

Thus we can postulate an aporia inherent in Levinas' conception of Saying as the pure, ethical essence of language. On one hand, Saying is the unspeakable that can never be translated into a theme; the beyond language as such or what is in language only insofar as it falls outside being - the trace of the originary dispossession. Yet, on the other hand, does not Saying also bespeak the traumatic loss of one's linguistic origin, of one's mother tongue, and the resulting experience of linguistic displacement? Saying signifies my eviction from chez soi, that is, from my linguistic community. If we consider Malka's repeated comments about the strangeness of Levinas' accent and his tortured French syntax, perhaps Levinas' articulation of Saying, which is stripped of all phenomenal markings of belonging, itself bears a trace of the traumatic disavowal of the loss of the mother tongue in the philosopher's work. Here it is telling that, in Otherwise than Being in particular, Levinas frequently borrows from the idiom of trauma to articulate the essence of ethical subjectivity: at the core of the ethical relation, there is "a deafening trauma, cutting the thread of consciousness which should have welcomed it in the present" (Otherwise 111). ${ }^{11}$ If we agree with Caygill's interpretation that Levinas' entire oeuvre is, at a certain level, a labour of mourning (Durcharbeitung), which entails, as we have insisted, working through the loss of the primary linguistic community, then the philosopher's transformative articulation of the essence of language as responsibility to the other is indeed a very powerful instance of bearing witness to that loss. 
In his essay "Poetics and Politics of Witnessing" Derrida brings out the relation between translation's crossing of linguistic frontiers and testimony's crossing the border between "an act of faith," that is, a subjective space of unconditional belief, and the order of knowledge where the proof of events has to be procured (78). Suspended between the two orders, testimony is always both an act of translation and an act that resists translation. "But," asks Derrida, "what would an untranslatable testimony be worth? Would it be non-testimony? And what would a testimony that was absolutely transparent to translation be? Would it still be testimony?" (69) Derrida concludes that the relation between translation and testimony is a necessary one, and it is maintained by this aporetic conundrum of testifying speech. It seems that a similar aporia bears upon Levinas' articulation of subjectivity as witness to the other and language as primarily Saying; moreover, it is inseparable from the dilemmas of translation that-silently-permeated his work and his life. In turn, insofar as testimony and translation are interrelated in their ethical orientation toward the other, these translatory peregrinations give force to the testimonial impetus in Levinas' work. As we recall, when Levinas was trying to explain why he did not write directly about the Shoah, he also enjoined his readers to listen to the inextinguishable cries that "echo and echo across eternity" ("Loving the Torah" 81, emphasis mine). After the Shoah, we can hear the same ethical injunction to bear witness to the voices of the past in Benjamin's question from "On the Concept of History": "Do we not, ourselves, feel a faint breath of the air in which people of yesterday lived? Do not the voices to which we lend our ears carry an echo of voices now extinguished?" (quoted in Didi-Huberman 170). Here again the recurrent metaphor of the echo brings forth the weight of the testimonial imperative.

The other's suffering is "useless suffering," inconvertible into meaning and impossible to appropriate or explain, not even, as Levinas argues (after Fackenheim), in terms of theodicy. Yet 
this absolute uselessness does acquire an ethical significance as "the suffering in me for the unjustifiable suffering of the other," which is a plea that elicits the self in its primordial and nonreciprocal responsibility (Levinas, "Useless Suffering" 94). Does it matter, however, in what national language the victims uttered their last cry, whether the victims of the Shoah or the victims of any violence, of "the same hatred of the other man"? Levinas himself admits, in response to Philippe Nemo's questions about the genesis of his philosophical project, that thinking "probably begins through traumatisms or gropings to which one does not even know how to give a verbal form" (Ethics and Infinity 21, emphasis mine). Although he refused or perhaps was not able to "give a verbal form" to his own sense of alienation from language, this estrangement may have been a traumatic kernel which, perhaps exactly because it remained disarticulated, deeply informed Levinas' thinking about language and in fact his entire philosophical endeavour. Here Heidegger's supreme valorization of silence as the most authentic moment in a dialogue "from house to house" might also illuminate Levinas' own silence, even though Levinas, appalled by the German philosopher's silence of indifference, would not have granted Heidegger that insight. The mainstay of Levinas' project is the thesis that a subject is primarily a witness to another human being, for whom he is always responsible. Behind that project stands an injunction that a philosopher bear witness to atrocity since he is always obligated by another's suffering, and it is for ethical reasons that Levinas disengaged himself from thematizing that suffering. If Benjamin postulates a task for a translator that, under scrutiny, has been revealed as an ethical task, Levinas enjoins us to radically recalibrate the task of the philosopher in ethical terms, as testimony to the glory of the Infinite. Yet this philosophical witness might be rooted in the philosopher's stunned silence about the loss of his linguistic community, in the "ensilenced word" (das erschwiegene Wort) (Celan 79) that also 
traverses the work dedicated to those closest to him, "the victims on National socialism, the same anti-semitism."

I lost a word that sought me:

Kaddish. (Celan 151)

\section{Notes}

${ }^{1}$ For an extended discussion of Derrida's commentary on Paul Celan in the context of translation and Holocaust testimony see Dorota Glowacka, “A Date, a Place, a Name: Jacques Derrida's Holocaust Translations" (2007).

2 In Robert Eaglestone's view, “the Holocaust saturates Levinas’ work” (255).

${ }^{3}$ Speaking of his love for the French language, Levinas notes: "I still speak Russian very well, German and Hebrew well enough; I read English, but I often thought, at the beginning of the war in 1939, that one waged war in order to defend French language" (Robbins 30).

${ }^{4}$ See, for instance, an interview with Arendt by journalist Günter Gaus, broadcast on West German television in 1964. Arendt stated, "I have always consciously refused to lose my mother tongue. I have always maintained a certain distance from French, which I then spoke very well, as well as from English, which I write today ... The German language is the essential thing that has remained and that I have always consciously preserved" (Arendt 13).

5 One of Levinas' students recalls that: "his language was certainly interesting ... a bit fantastical, behind which lay Russian, German, and Hebrew” (Malka 152).

${ }^{6}$ As Wiesel reminisces in his autobiography All Rivers Run to the Sea (1995), he and Levinas once met in person, and Levinas praised Wiesel's work by describing it as "kiddush hashem" (the sanctification of the Lord's name). The two had the same teacher of the Talmud, a mysterious figure known in Paris as Monsieur Shoshani.

${ }^{7}$ See Barbara Engelking-Boni's Na łące popiołów: Ocaleni z Holocaustu (1993) and Holocaust and Memory (2001).

${ }^{8}$ Among the scholars who have written about translation in Holocaust testimony are: Anette Wieviorka in The Era of the Witness (2006), Alan Rosen in Sounds of Defiance (2005), Imre Kertész in Język na wygnaniu [Language in exile] (2004), Susan Rubin Suleiman in "Monuments in the Foreign Tongue: On Reading Holocaust Memoirs by Emigrants" (1996), and Berel Lang in "Translating the Holocaust: For Whom Does One Write?" (1999).

${ }^{9}$ For the discussion of the cabbalistic concept of tikkun (messianic mending and restoration) in relation to Benjamin's essay see Carol Jacobs" “The Monstrosity of Translation” (1975). 
${ }^{10}$ Fearing that her husband might fall victim to the collaborationist Vichy government's policy of denaturalizing French Jews (which would inevitably spell transportation to the Nazi death camps in the east), Raïssa Levinas petitioned the President of the Commission of Revisions of Naturalizations to stay his French citizenship on the grounds of his contributions to the French army as a member of the corps of military interpreters (Malka 66).

${ }^{11}$ For an analysis of an attunement between Levinas' project and psychoanalysis, despite the philosopher's rejection of psychoanalysis as such, see Bettina Bergo's "What Is Levinas Doing? Phenomenology and the Rhetoric of an Ethical Un-Conscious" (2005). Bergo shows a similarity between Levinas' conception of the pre-egological, pre-reflective, and primarily affective subject and Freud's notion of the unconscious. For an analysis of Levinas' use of trauma (traumatisme) as the cipher of the ethical relation and the "immemorial past" in which it originates, see Michael Newman's "Sensibility, Trauma, and the Trace: Levinas from Phenomenology to the Immanence" in The Face of the Other and the Trace of God: The Ethical Philosophy of Emmanuel Levinas (2000).

\section{Works Cited}

Améry, Jean. At the Mind's Limits. Trans. Sidney Rosenfeld and Stella P. Rosenfeld. New York: Schocken Books, 1986.

Arendt, Hannah. Essays in Understanding, 1930-1954: Formation, Exile, and Totalitarianism. Ed. Jerome Kohn. New York: Schocken Books, 2005.

Benjamin, Walter. Illuminations. Ed. Hannah Arendt. New York: Schocken Books, 1969.

—. Reflections. Trans. Edmund Jephcott. New York: Schocken Books, 1986.

Bergo, Bettina. "What Is Levinas Doing? Phenomenology and the Rhetoric of an Ethical UnConscious." Philosophy and Rhetoric 38.2 (2005): 122-44.

Caruth, Cathy. Unclaimed Experience: Trauma Narrative, and History. Baltimore: The Johns Hopkins University Press, 1996.

Caygill, Howard. Levinas and the Political. London: Routledge, 2002.

Celan, Paul. Selected Poems and Prose of Paul Celan. Trans. John Felstiner. New York: W.W. Norton, 2001.

De Man, Paul. The Resistance to Theory. Minneapolis: Minnesota University Press, 1986.

Derrida, Jacques. Adieu to Emmanuel Levinas. Trans. Pascale-Anne Brault and Michael Naas. Stanford: Stanford University Press, 1999. 
—_. "Des Tours de Babel." Difference in Translation. Ed. Joseph F. Graham. Ithaca: Cornell University Press, 1985. 165-205.

- Sovereignties in Question: The Poetics of Paul Celan. Ed. Thomas Dutoit and Outi Pasanen. New York: Fordham University Press, 2005.

Didi-Huberman, Georges. Images in Spite of All: Four Photographs from Auschwitz. Trans. Shane B. Lillis. Chicago and London: The University of Chicago Press, 2008.

Eaglestone, Robert. The Holocaust and the Postmodern. Oxford: Oxford University Press, 2004.

Engelking, Barbara. Holocaust and Memory. London and New York: Leicester University Press 2001. . Na łace popiołów: Ocaleni z Holocaustu. Warsaw: Cyklady 1993.

Fackenheim, Emil. To Mend the World: Foundations of Post-Holocaust Jewish Thought. Bloomington: Indiana University Press, 1994.

Glowacka, Dorota. “A Date, a Place, a Name: Jacques Derrida's Holocaust translations.” CR: The New Centennial Review 7.2 (2007): 111-140.

Heidegger, Martin. Basic Writings. Ed. David Farrell Krell. New York: Harper and Row, 1977.

—. On the Way to Language. Trans. Peter D. Hertz. New York: Harper and Row, 1971.

Jacobs, Carol. “The Monstrosity of Translation.” MLN 90 (1975): 755-66.

Kertész, Imre. Język na wygnaniu. Warsaw: Wydawnictwo WAB, 2004.

Lang, Berel. "Translating the Holocaust: For Whom Does One Write?” Judaism 48.3 (1999): 334-5.

Levi, Primo. The Drowned and the Saved. Trans. Raymond Rosenthal. New York: Vintage Books, 1988.

—. Survival in Auschwitz: The Nazi Assault on Humanity. Trans. Stuart Woolf. New York: Collier Books, 1993.

Levinas, Emmanuel. "As If Consenting to Horror." The Heidegger Controversy. Ed. Richard Wolin. Cambridge: The MIT Press, 1993. 485-488.

—. Ethics and Infinity. Trans. Richard A. Cohen. Pittsburgh: Duquesne University Press, 1985. 
—. God, Death, and Time. Trans. Bettina Bergo. Stanford: Stanford University Press, 2000.

_ . "Loving the Torah More than God." Afterword. Yosl Rakover Talks to God. Zvi Kolitz. New York: Pantheon Books, 1999. 79-87.

- Otherwise Than Being or Beyond Essence. Trans. Alphonso Lingis. Pittsburgh: Duquesne University Press, 1998.

—_. "Useless Suffering." Entre Nous: Thinking-of-the-Other. Trans. Michael B. Smith and Barbara Harshav. New York: Columbia University Press, 1998. 91-102.

—_. "Signature." Difficult Freedom. Trans. Seán Hand. Baltimore: Johns Hopkins University Press, 1990. 291-295.

—. "Struthof Case." Difficult Freedom. Trans. Seán Hand. Baltimore: Johns Hopkins University Press, 1990. 149-150.

__. "Language and Proximity." Collected Philosophical Papers. Trans. Alphonso Lingis. The Hague: Martinus Nijhoff, 1987.

- Totality and Infinity. An Essay on Exteriority. Trans. Alphonso Lingis. Pittsburgh: Duquesne University Press, 1969.

—. "The Trace of the Other." Deconstruction in Context. Ed. Mark C. Taylor. Chicago: University of Chicago Press, 1986. 345-359.

Malka, Salomon. Emmanuel Levinas: His Life and Legacy. Trans. Michael Kigel and Sonja M. Embree. Pittsburgh: Duquesne University Press, 2006.

Mortley, Raoul. "Emmanual Levinas" (1991). French Philosophers in Conversation: Levinas, Schneider, Serres, Irigaray, Le Deouff, Derrida. London and New York: Routledge, 1991. 10-23. Web. May 1, 2011.

Newman, Michael. "Sensibility, Trauma, and the Trace: Levinas from Phenomenology to the Immanence." The Face of the Other and the Trace of God: The Ethical Philosophy of Emmanuel Levinas. Ed. Jeffrey Bloechl. New York: Fordham University Press, 2000. 90129.

Robbins, Jill. Is It Righteous to be? Interviews with Emmanuel Levinas. Stanford: Stanford University Press, 2001.

Rosen, Alan. Sounds of Defiance: The Holocaust, Multilingualism, and the Problem of English. Lincoln and London: University of Nebraska Press, 2005. 
Saint Cheron, Michaël de. Conversations with Emmanuel Levinas, 1983 - 1994. Trans. Gary D. Mole. Pittsburgh: Duquesne University Press, 2010.

Suleiman, Susan Rubin. "Monuments in the Foreign Tongue: On Reading Holocaust Memoirs by Emigrants.” Poetics Today 17.4 (1996): 639-57.

The Holy Bible. Philadelphia, Penn.: National Bible Press, 1943.

Wiesel, Elie. All Rivers Run to the Sea: Memoirs. New York: Alfred A. Knopf, 1995.

Wieviorka, Anette. The Era of the Witness. Ithaca: Cornell University Press, 2006. 